\title{
“TUDO O QUE EXISTE PRECISA SER SALVO": UMA LEITURA DE \\ “AMOR”, DE CLARICE LISPECTOR.
}

\author{
"EVERYTHING THERE IS NEEDS TO BE SAVED": A READING OF \\ “LOVE", BY CLARICE LISPECTOR.
}

Mateus Toledo Gonçalves (UFPR)

mateus_tg@hotmail.com

\begin{abstract}
RESUMO: Esse artigo é uma leitura de "Amor", de Clarice Lispector. O artigo acompanha o conto basicamente parágrafo a parágrafo até a cena crucial do Jardim Botânico. A filosofia do rosto de Emmanuel Levinas será um referencial importante para pensar o evento da narrativa, em que a protagonista avista do bonde o cego mascando chicles. Esse evento terá "repercussões ontológicas" no conto, como argumentaremos, no que a referência à filosofia levinasiana será decisiva. Esse referencial, no entanto, será relativizado na literatura de Clarice Lispector, por meio da desestabilização da partilha entre o que é meramente um objeto e o que pode deter um rosto.
\end{abstract}

PALAVRAS-CHAVE: Clarice Lispector; “Amor”; Emmanuel Levinas; Rosto.

ABSTRACT: This paper has as purpose to analyze the short story "Amor", by Clarice Lispector. The article follows the story basically paragraph by paragraph until the crucial scene at the Botanical Garden takes place. The philosophy of the face of Emmanuel Levinas will be an important reference to think about the story main event, in which the protagonist sees the blind man chewing gum. This event will have ontological repercussions in the story, as we will argue with the support from Levinasian philosophy. However, this framework coming from Levinas' philosophy will be relativized in the story itself, through the destabilization of the division between what is merely an object and what can have a face.

KEYWORDS: Clarice Lispector; "Love”; Emmanuel Levinas; Face. 
Em seu "Excurso sobre a sociologia dos sentidos", espécie de irmão desconhecido do muito mais eminente "A metrópole a vida mental”, George Simmel se permite a certa altura (e de passagem) especular sobre os incalculáveis efeitos que um eventual fim da troca de olhares, da experiência da visão recíproca no rosto de um conterrâneo, teria sobre a sociabilidade humana (SIMMEL, 1908, p. 647-648). O ponto ali era mostrar que entender "o significado sociológico do olho" (SIMMEL, 1908, p. 648) envolve esclarecer o sentido em que o "social" está em larga medida fundado num reconhecimento recíproco que só é possível pela experiência aparentemente banal da interação olho no olho. Contra uma larga tradição filosófica, que tem no olho como antes de tudo o órgão da percepção distante e neutra e por isso prototipicamente ligado ao conhecimento objetivo, Simmel vai tomar o olho como um órgão social, privilegiando nele o seu condão de gerar a reciprocidade entre os homens.

A emergência das grandes cidades na passagem do século XIX para o XX, no entanto, teria criado uma situação nova, que ameaçaria esse reconhecimento mútuo disparado pelo olhar. Há uma cena típica das cidades modernas, em que é perfeitamente possível estar sentado diante de alguém, por vezes por longos períodos, sem que essa proximidade resulte num reconhecimento mútuo. Situação em que os olhares se alternam se evitando e, quando eventualmente se encontram, a troca de olhares não desemboca em reciprocidade, pois nenhuma palavra é trocada, nenhum elo é gerado, os olhares se cruzam sem poder se entender. Essa cena nova é a locomoção por transporte público nas grandes metrópoles (SIMMEL, 1908, p.651).

É esse também o cenário de "Amor", de Clarice Lispector, que abre com a personagem Ana em um bonde e que vai narrar um evento disparado pela visão de um rosto, um olhar não reciprocado, com repercussões profundas, um abalo de proporções ontológicas (NODARI, 2022, s/p) que tentarei descrever nesse artigo.

Um pouco cansada, com as compras deformando o novo saco de tricô, Ana subiu no bonde. Depositou o volume no colo e o bonde começou a andar. Recostou-se então no banco procurando conforto, num suspiro de meia satisfação. (LISPECTOR, 2016, p. 145)

“Amor” talvez seja o conto mais paradigmático de Clarice. Não é, por certo, uma casualidade que três diferentes críticos, Benedito Nunes, Affonso Romano de Sant'anna e Luiz Costa Lima, quando vão articular um tipo de esquema geral abstrato que eles encontram na obra de Clarice, forneçam precisamente "Amor" como exemplo. De fato, esse conto parece 
condensar várias linhas de força da obra de Clarice e revela de maneira particularmente clara um certo arranjo recorrente: uma personagem é colocada numa situação de (aparente) tranquilidade e segurança. Essa tranquilidade é, contudo, uma ordenação instável que depende da domesticação “da potência agressiva do mundo" (LIMA, 1969, p. 328), que permanece como latência no início do conto. Há, então, um evento, o "momento de tensão conflitiva" (NUNES, 1989, p. 84), em que essa potência irrompe e produz-se uma crise. Por fim, no desfecho haveria uma suposta volta à normalidade, com a vertigem presente no centro do conto "se diluindo" (SANT'ANNA, 1973, p. 190), de modo que o que irrompeu retornaria ao estado de "latência de onde emergira" (NUNES, 1989, p. 86). Se esse tipo de esquema, que será relativizado no decorrer do artigo, não deixa, é claro, de ter o seu parti pris e é demasiado genérico para um exame pormenorizado do conto - ele é feito, afinal, para abarcar uma variedade de contos e mesmo de romances —, é notável, porém, como ele parece particularmente se acomodar ao caso de "Amor", como se esses três diferentes críticos tomassem o conto como a narrativa exemplar clariciana.

Essa ideia de que há uma ordenação, uma forma, que como que procura conter uma espécie de princípio vital, algo latente e que ameaça rebentar, de certo modo está colocada desde o primeiro período de "Amor": ela terá como emblema no conto o saco de tricô no colo de Ana. Trata-se de uma rede com um certo emprego — algo que serve para encerrar dentro de si alguma coisa que se mantém (quase) oculta e que ameaça irromper - e com uma dimensão artesanal, decorativa, que atende a um desejo "vagamente artístico" da personagem, um ímpeto ordenador. O saco de tricô é obra da personagem (numa atividade estereotipicamente vinculada à casa e ao feminino, a tricotagem) e sua rede parece simbolizar os próprios laços de família, que dão título à coletânea, laços que ao mesmo tempo conectam (tecem os elos no interior da casa, fabricam o tecido familiar) e aprisionam (são "instrumentos de domesticação" (NODARI, 2022, s/p), servem para conter "a potência agressiva do mundo").

\footnotetext{
Os filhos de Ana eram bons, uma coisa verdadeira e sumarenta. Cresciam, tomavam banho, exigiam para si, malcriados, instantes cada vez mais completos. A cozinha era enfim espaçosa, o fogão enguiçado dava estouros. O calor era forte no apartamento que estavam aos poucos pagando. Mas o vento batendo nas cortinas que ela mesma cortara lembrava-lhe que se quisesse podia parar e enxugar a testa, olhando o calmo horizonte. Como um lavrador. Ela plantara as sementes que tinha na mão, não outras, mas essas apenas. E cresciam árvores. Crescia sua rápida conversa com o cobrador de luz, crescia a água enchendo o tanque, cresciam seus filhos, crescia a mesa com comidas, o marido chegando com os jornais e sorrindo de fome, o canto importuno das empregadas do edifício. Ana dava a tudo, tranquilamente, sua mão pequena e forte, sua corrente de vida (LISPECTOR, 2016, p. 145).
} 
Se o primeiro parágrafo tem início no meio dos acontecimentos, com a personagem prestes a vivenciar o "evento" do conto, o segundo parágrafo introduz um interlúdio, um flashback que interrompe a ação e faz um retrospecto da vida de Ana. Notável que o parágrafo, espécie de síntese do papel da mulher no domínio da família de classe média da época, parece figurar a inserção da protagonista na ordem doméstica como bem ajustada, com Ana reconciliada na sua inscrição nos laços familiares. Carlos Mendes de Sousa, comentando esse início do conto, vai ler aqui, no entanto, um “jogo irônico”, em que o narrador sorrateiramente denuncia esse "falso apaziguamento" da personagem, pela maneira como a voz de Ana se imiscui na enunciação" (SOUSA, 2000, p. 113). O pensamento "sensato", resignado, de Ana, se manifestaria em certas adjetivações ("os filhos de Ana eram bons, uma coisa verdadeira", seu marido era "um homem verdadeiro", que lhe dera "filhos verdadeiros") ou no uso do advérbio "tranquilamente". E o jogo ardiloso estaria no fato de que essa intromissão da protagonista na narração em terceira pessoa seria, em verdade, uma denegação, que afirma o que pretende negar: nós sabemos, dirá Carlos Mendes de Sousa, que "a verdadeira vida" é a que a Ana vai experimentar no Jardim Botânico e, poderíamos acrescentar, sabemos também que essa "tranquilidade" é uma fachada que recalca a vertigem latente que ameaça irromper (SOUSA, 2000, p. 113). Não é preciso aderir totalmente a essa leitura, que torna exclusivas duas alternativas que poderiam coexistir (nada impede que os filhos de Ana e também a experiência do Jardim sejam, ao mesmo tempo, "verdadeiros"), mas ela aponta, de todo modo, para um tipo de duplicidade presente no conto que é crucial.

\footnotetext{
${ }^{1}$ Comentando exatamente o mesmo parágrafo, João Camillo Penna vai fazer um comentário muito elucidativo sobre a ambiguidade peculiar da voz narrativa clariciana. Cito: "A especificidade da voz narrativa de Lispector é clara nesse caso. Embora não tenha tempo para me alongar sobre isso por enquanto, é suficiente apontar que a passagem não está nem em discurso indireto (não há nenhum verbo introdutório, como "ela pensou”), nem em discurso indireto livre (seria implausível e irrealista ter Ana dando um relato interior de toda sua existência; além disso, a passagem contém estilismos literários que devem ser atribuídos ao narrador), nem pode simplesmente ser atribuída a um narrador onisciente (ela contém traços afetivos que pertencem à personagem), nem é um monólogo interior (ela está na terceira pessoa e no pretérito). Uma das verdadeiras descobertas do estilo de Lispector reside precisamente nessa contaminação dos afetos das personagens no narrador onisciente, o que confere à voz narrativa a sua ambiguidade absolutamente indecidível, ao mesmo tempo irônica e identificada, crítica e simpática, distante e próxima." (PENNA, 1993, s/p, tradução minha). No original: The particular character of Lispector's narrative voice is clear in this instance. Although I do not have the time to dwell on that for the time being, it suffices to point out that the passage is neither in indirect speech (no introductory verb, such as "she thought"), nor in free indirect speech (it would be unplausible and unrealistic to have Anna give an interior account of her whole existence; furthermore the passage contains literary stylisms, which should be attributable to the narrator), nor can it be attributed simply to an omniscient narrator (it contains affective traits which belong to the character), nor is it an interior monologue (it is in the third person and in the past tense). One of the true findings of Lispector's style resides precisely in this contamination of the character's affects in the omniscient narrator, which provides the narrative voice with its absolutely undecidable ambiguity: at once ironic and identified, critical and sympathetic, distant and close.
} 
Duplicidade ou ambivalência que vai aparecer de modo decisivo nas metáforas vegetais do conto. Uma trama de imagens que envolve "sementes", "lavrador", "árvores" vai como que ordenar esse parágrafo que recapitula a vida de Ana. Nesse momento, essa teia metafórica parece simbolizar fixidez, mansidão, uma espécie de placidez vinculada à regularidade (notar o ritmo produzido pelas repetições) e como que marca uma inserção pacata e segura nos laços familiares. Essa imagética vegetal, contudo, vai aos poucos se metamorfoseando, revelando sua ambivalência; o próximo parágrafo já abre com a imagem macabra das árvores rindo da protagonista e adiante, na cena emblemática do Jardim Botânico, as plantas terão ganho um sentido completamente oposto, ligado a um descaminho na estranheza selvagem da vida.

Certa hora da tarde era mais perigosa. Certa hora da tarde as árvores que plantara riam dela. Quando nada mais precisava de sua força, inquietava-se. No entanto sentia-se mais sólida do que nunca, seu corpo engrossara um pouco e era de se ver o modo como cortava blusas para os meninos, a grande tesoura dando estalidos na fazenda. Todo o seu desejo vagamente artístico encaminhara-se há muito no sentido de tornar os dias realizados e belos; com o tempo seu gosto pelo decorativo se desenvolvera e suplantara a íntima desordem. Parecia ter descoberto que tudo era passível de aperfeiçoamento, a cada coisa se emprestaria uma aparência harmoniosa; a vida podia ser feita pela mão do homem (LISPECTOR, 2016, p. 145-146).

Os sinais de que essa inscrição de Ana nos laços familiares é instável, que ela não é assim tão garantida e tranquila, começam a aparecer e têm a forma de uma latência. A inadequação não se expressa nesse primeiro momento na forma de um conflito aberto, mas como algo que está escondido e deve ser reprimido, pois ameaça a ordem doméstica. E é no fim da tarde, quando cessam as tarefas domésticas, que o risco da irrupção se dá. O que já revela que a principal estratégia de repressão da "íntima desordem" será o engajamento contínuo e obsessivo nas tarefas da casa. Há uma espécie de embotamento que é alcançado pelo hábito, pela inconsciência da ação repetida. "O automatismo da percepção", certa feita o grande inimigo da literatura, é ironicamente o alvo do "desejo artístico" de Ana, que é no conto o desejo de uma ordenação que suplante a estrangeira desordem da protagonista.

No fundo, Ana sempre tivera necessidade de sentir a raiz firme das coisas. E isso um lar perplexamente lhe dera. Por caminhos tortos, viera a cair num destino de mulher, com a surpresa de nele caber como se o tivesse inventado. O homem com quem casara era um homem verdadeiro, os filhos que tivera eram filhos verdadeiros. Sua juventude anterior parecia-lhe estranha como uma doença de vida. Dela havia aos poucos emergido para descobrir que também sem a felicidade se vivia: abolindo-a, encontrara uma legião de pessoas, antes invisíveis, que viviam como quem trabalha - com persistência, continuidade, alegria. O que sucedera a Ana antes de ter o lar estava para sempre fora de seu alcance: uma exaltação perturbada que tantas vezes se confundira com felicidade insuportável. Criara em troca algo enfim compreensível, uma vida de adulto. Assim ela o quisera e escolhera (LISPECTOR, 2016, p. 146). 
A narração se situa mais uma vez em um registro engenhosamente ambíguo. Por um lado, faz-se um retrospecto da vida da protagonista que parece ter um posicionamento marcado: a justificação do enredamento de Ana na ordem doméstica. O narrador lembra que Ana aplaca com o matrimônio uma necessidade "de sentir a raiz firme das coisas", que sua vida antes do casamento era uma "doença" ou uma "exaltação perturbada", que seu destino de mulher foi sua “invenção" e que "assim ela o quisera e escolhera". Por outro lado, no entanto, como que escapa pelas metáforas usadas, pelas expressões tensionadas e pelo fraseado sinuoso a equivocação de cada um dos pontos desse arrazoado. As metáforas vegetais no conto, como já comentado, são ambivalentes: se a imagem da raiz aponta para a necessidade de fixidez e de estabilidade e, portanto, para o enredamento nos laços familiares; ela expressa também um desejo de ir ao fundamento das coisas e de experimentar o mundo em sua radicalidade, a raiz liga a personagem ao Jardim Botânico. Por sua vez, se a juventude anterior ao matrimônio era doença, era, contudo, uma "doença de vida", expressão tensionada, em que o adjunto "de vida" nega o substantivo, equivocando a expressão. Por fim, se o parágrafo termina dizendo que Ana "escolhera e quisera" o seu destino, ele abre com uma frase sinuosa, que afirma isso e o seu oposto: Ana “caiu no destino de mulher", i.e., não o escolheu; mas, ao mesmo tempo, é "como se o tivesse inventado", o que é mais do que o escolher, é tê-lo criado.

\footnotetext{
Sua precaução reduzia-se a tomar cuidado na hora perigosa da tarde, quando a casa estava vazia sem precisar mais dela, o sol alto, cada membro da família distribuído nas suas funções. Olhando os móveis limpos, seu coração se apertava um pouco em espanto. Mas na sua vida não havia lugar para que sentisse ternura pelo seu espanto - ela o abafava com a mesma habilidade que as lides em casa lhe haviam transmitido. Saía então para fazer compras ou levar objetos para consertar, cuidando do lar e da família à revelia deles. Quando voltasse era o fim da tarde e as crianças vindas do colégio exigiam-na. Assim chegaria a noite, com sua tranquila vibração. De manhã acordaria aureolada pelos calmos deveres. Encontrava os móveis de novo empoeirados e sujos, como se voltassem arrependidos. Quanto a ela mesma, fazia obscuramente parte das raízes negras e suaves do mundo. E alimentava anonimamente a vida. Estava bom assim. Assim ela o quisera e escolhera (LISPECTOR, 2016, p. 146-147).
}

Último parágrafo do flashback, que recapitula a rotina da personagem, abre novamente apontando para uma estranheza latente, um perigo à espreita que ameaça perturbar o equilíbrio instável que assegura a tranquilidade da casa, perigo que Ana tenta suprimir por uma diligente super-ocupação: a inconsciência do hábito, a repetição da ação que invisibiliza as coisas e o mundo, é o que "abafa" a íntima desordem, o hábito zelando pela habitação.

Essa dimensão latente é também entrevista nas ambivalências das metáforas e nos atos falhos. Reaparece a imagem dúplice das raízes, já comentada, mas agora elas são "negras", 
prenunciando a noite escura porvir. E o parágrafo termina repetindo exatamente a mesma frase que finalizou o parágrafo anterior, numa tentativa insistente de nos convencer da adequação de Ana à ordem doméstica, o que, no entanto, parece ter o efeito contrário, a repetição trai, em verdade, uma insegurança, como se a narração não estivesse assim tão convicta do que diz e tentasse convencer a si própria.

É como se, nesses primeiros parágrafos, a leitora e o leitor fossem chamados a procurar esses índices de inadequação de Ana à ordem doméstica, um chamado, no entanto, que está sempre em tensão com um movimento simultâneo do conto que tenta os velar, como se todo o jogo desse início fosse esse, um convite para que espiemos por entre a trama dos fios do saco de tricô, buracos que deixam entrever um princípio de desordem latente, e que a rede procura de todas as formas ocultar e conter.

\section{II}

Feito o flashback, o conto voltará à cena inicial, em que Ana está sentada no bonde com seu saco de tricô no colo, na iminência de um evento desorganizador, a vista do cego mascando chicletes. O cenário desse encontro, como já comentado, não é insignificante. Como já mencionado, Simmel nota que a emergência das grandes cidades teria produzido uma situação nova, que ameaçava a experiência do "olhar recíproco": o transporte público metropolitano. De sorte que poderíamos dizer que não é apenas a personagem de Ana que está prestes a vivenciar uma crise, mas que o cenário em que esse evento se dá seria ele mesmo o emblema de uma outra crise mais geral, atado a uma nova disposição socio-sensorial própria das grandes cidades. Vale insistir que já em Simmel esse reconhecimento recíproco pelo olhar é tomado como de grandes consequências e significado: talvez não seja exagero dizer que para o sociólogo boa parte da ordem social se sustenta nessa experiência corriqueira da interação olho no olho. Foi outro pensador, no entanto, que elevou essa experiência aparentemente banal à condição de princípio último de sua filosofia. E embora ele estivesse tratando igualmente de um tipo de reconhecimento disparado pelo olhar, sua ênfase estava não tanto no ato de percepção, mas naquilo que é mirado por essa modalidade de olhar: o rosto. ${ }^{2}$

\footnotetext{
${ }^{2}$ Cumpre notar, por razões de precisão conceitual, que o tipo de acesso que temos do rosto do outro, para Levinas, não é propriamente visual ou perceptivo. Se também em Levinas - como em Simmel - a situação em questão é aquela em que se está diante do rosto do outro, "olho-no-olho"; o rosto, no entanto, não seria para ele propriamente da ordem do visível. O tipo de apelo que o "rosto" tem sobre nós é pré-perceptivo, anterior a visualidade. (LEVINAS, 1982, p. 69)
} 
Emmanuel Levinas articula toda uma filosofia que tem no conceito de "rosto" o seu ponto de fuga. Em um sentido inicial, seria possível dizer, como faz Judith Butler em seu comentário sobre a obra do filósofo lituano, que a noção de "rosto" é introduzida para explicar a gênese da capacidade que os outros têm de nos fazer apelos morais (BUTLER, 2004, p. 131). A solução para o enigma da origem da ética estaria na experiência do rosto do outro, é nele que ela estaria fundada. Para Levinas, o rosto teria o poder de colocar o eu em questão: ele nos confronta e somos chamados a responder ao seu apelo. O rosto em sua nudez, em sua vulnerabilidade e pobreza essencial, nos convida inicialmente a um ato de violência, mas, em seguida, ele o proíbe: o imperativo do rosto, o que ele nos "diz" sem palavras, é um "tu não matarás", é essa sua injunção fundamental (LEVINAS, 1982, p. 69-70).

Uma maneira de entender esse ponto, que pode parecer à primeira vista obscuro, seria dizer que Levinas está apontando para um aspecto da nossa experiência ordinária que seria tão evidente que nós o esquecemos. Há uma partilha fundamental que diferencia a maneira como nos relacionamos, de um lado, com os objetos em geral e, do outro, com aquilo que detém um rosto. Podemos conhecer, possuir, nomear, classificar os objetos em geral. Se as coisas são apenas coisas, o mundo se apresenta como algo que está à disposição de nós, nós as possuímos. A presença do rosto, no entanto, interrompe essa dinâmica: num nível fundamental, o outro é mais do que uma coisa. O rosto tem o poder de nos interpelar, nos endereça um apelo, e, portanto, rompe com essa ordem da objetualidade. Levinas não nega com isso, por óbvio, que com frequência dominamos os outros. A questão é que, diante de um rosto, ainda que eu pretenda manipulá-lo, serei interpelado por algo que pela mera presença me diz "não", algo cujo ser impõe resistência aos meus desígnios, de maneira que, a despeito "da extensão do meu domínio sobre ele e de sua submissão, eu não o possuo" (LEVINAS, 1997, p. 31). O rosto interrompe essa ordem da objetualidade pelo imperativo negativo que o constitui:

A absoluta nudez do rosto, este rosto absolutamente indefeso, sem cobertura, sem
roupa, sem máscara é, no entanto, o que se opõe ao meu poder sobre ele, à minha
violência, o que se opõe de forma absoluta, de uma oposição que é a oposição em si
mesma. O ser que se expressa, o ser que está em face de mim [que me encara] me diz
'não', por sua expressão mesma. Este 'não' não é apenas formal, mas também não é
um 'não' de uma força hostil ou de uma ameaça; é a impossibilidade de matar que
apresenta esse rosto, é a possibilidade de encontrar um ser através de uma proibição.
O rosto é o fato de que um ser nos afeta não no indicativo, mas no imperativo e, assim,
de estar fora de qualquer categoria. (LEVINAS, 1953, p. 270, tradução minha)

\footnotetext{
${ }^{3}$ No original: "L'absolue nudité du visage, ce visage absolument sans défense, sans couverture, sans habillement, sans masque est cependant ce qui s'oppose à mon pouvoir sur lui, à ma violence, ce qui s'y oppose d'une manière absolue, d'une opposition qui est opposition en soi. L'être qui s'exprime, l'être qui est en face de moi me dit non,
} 
A noção de "rosto" está no centro de sua filosofia. Para Levinas a linguagem estaria “fundada numa relação anterior à compreensão" e "que constitui a razão", e essa relação seria precisamente o encontro com o rosto do outro (LEVINAS, 1997, p. 26). Numa argumentação que Levinas desenvolve em seu Totalidade e Infinito - e que não seria viável reproduzir aqui — não apenas a linguagem e a razão se revelariam como assentadas nessa relação anterior, o encontro com outro, mas também as noções de objetividade, de evidência (LEVINAS, 1980 p. 183) e a própria ideia de mundo, enquanto um mundo comum, partilhado (LEVINAS, 1980, p. 155-156). Poderíamos argumentar, num fraseado e vocabulário não propriamente levinasiano, que o "rosto" funcionaria em sua filosofia como uma espécie de condição transcendental.

$\mathrm{O}$ conto que estamos comentando narra basicamente a visão de um rosto e suas repercussões. Esse olhar produz uma crise que não seria exagero chamar de ontológica. Poderíamos dizer que é como se as próprias condições que tornam possível a experiência da protagonista do conto entrassem em parafuso quando ela vê o rosto do cego mascando chicletes. Seria possível, para pensar o caso do conto, partir de uma intuição, avizinhada da levinasiana, que afirmasse que o tipo de relação com o rosto do outro e também a partilha fundamental que divide aquilo que pode ou não ter rosto é constituidora de mundo, opera como uma espécie de condição transcendental que, se alterada, produz um abalo de repercussões ontológicas.

\begin{abstract}
O bonde vacilava nos trilhos, entrava em ruas largas. Logo um vento mais úmido soprava anunciando, mais que o fim da tarde, o fim da hora instável. Ana respirou profundamente e uma grande aceitação deu a seu rosto um ar de mulher. $\mathrm{O}$ bonde se arrastava, em seguida estacava. Até Humaitá tinha tempo de descansar. Foi então que olhou para o homem parado no ponto. A diferença entre ele e os outros é que ele estava realmente parado. De pé, suas mãos se mantinham avançadas. Era um cego. O que havia mais que fizesse Ana se aprumar em desconfiança? Alguma coisa intranquila estava sucedendo. Então ela viu: o cego mascava chicles... Um homem cego mascava chicles. Ana ainda teve tempo de pensar por um segundo que os irmãos viriam jantar - o coração batia-lhe violento, espaçado. Inclinada, olhava o cego profundamente, como se olha o que não nos vê. Ele mastigava goma na escuridão. Sem sofrimento, com os olhos abertos. O movimento da mastigação fazia-o parecer sorrir e de repente deixar de sorrir, sorrir e deixar de sorrir - como se ele a tivesse insultado, Ana olhava-o. (LISPECTOR, 2016, p. 147)
\end{abstract}

Terminada a recapitulação da vida de Ana, somos jogados imediatamente no evento do conto, a visão do cego mascando chicletes. Momento de súbita ruptura, que, no entanto, é preparado desde o início conto, nas referências constantes a um perigo iminente que ameaçava

\footnotetext{
par son expression même. Ce non n'est pas simplement formel, mais il n'est pas non plus celui d'une force hostile ou d'une menace ; il est impossibilité de tuer celui qui présente ce visage, il est la possibilité de rencontrer un être à travers une interdiction. Le visage, c'est le fait pour un être de nous affecter, non pas à l'indicatif, mais à l'impératif, et d'être ainsi extérieur à toute catégorie".
} 
irromper. Mesmo o começo dessa cena, a imagem de um bonde que "vacila" nos trilhos, já se opõe à descrição anterior da vida de Ana, marcada pela estabilidade e seu enraizamento, e de certa forma antecipa a crise porvir.

O que dispara a desestruturação do mundo de Ana é a visão do cego. Como sempre ocorre na literatura de Clarice, o momento de revelação desorganizante se dá no encontro com o outro (NODARI, 2022, s/p). E, poderíamos acrescentar, é sempre na visão do rosto de um outro. Basta pensar no caso mais paradigmático desse encontro na obra de Clarice, A paixão segundo G.H.. Lá a narradora não vê simplesmente uma barata, ela se depara com o seu rosto, rosto que significativamente paralisa o seu ímpeto assassino ${ }^{4}$.

O cego mirado por Ana é descrito no conto como aquele que "não nos vê", que não pode reciprocar o olhar, e está mascando "chicles". Chicletes que, como vai notar Regina Pontieri, estão ligados a um motivo recorrente na obra de Clarice:

\begin{abstract}
"O elemento viscoso ou pastoso é frequente e de fundamental importância para a construção do significado total na obra de Clarice: é a matéria que escorre de dentro dos ovos partidos ou o chicle mascado pelo cego, em 'Amor'; a massa que sai lentamente pela fenda do corpo da barata, em A paixão segundo G.H., a substância gelatinosa envolvendo a narrador de um pesadelo, no fragmento 'A geleia viva' (...) a imagem remete a uma experiência inaugural que, por sê-lo, inscreve-se no corpo de uma matéria anterior à forma". (PONTIERI, 1999, p. 94-95)
\end{abstract}

O cego mascando chiclete está em relação com uma matéria anterior à forma, o que Clarice com frequência chama de coisa. A mastigação também é significativa no conto, ela dá ao homem, como vai notar João Camillo Penna, uma aparência maquinal, que estaria expressa ritmicamente nas repetições do trecho: "O cego mascava chicles... Um homem cego mascava chicles", "O movimento da mastigação fazia-o parecer sorrir e de repente deixar de sorrir, sorrir e deixar de sorrir" (LISPECTOR, 2016, p. 147). O gesto mecânico de mastigar como que retira do rosto sua expressão: não há ali uma interioridade se manifestando, sua fisionomia nada revela (PENNA, 1993, s/p). O que perturba Ana é a visão de uma coisa dotada de um rosto.

"Ele mastigava goma na escuridão", diz a narração, numa frase que soa a fala espantada da protagonista. A frase descreve o gesto do cego na terceira pessoa, o toma nesse sentido como objeto - ele é visto de fora - mas ela também incorpora, por seu turno, a perspectiva do cego, ele mastiga chicletes na escuridão. Há uma espécie de obliquação em cadeia, em que o narrador

\footnotetext{
4 "Um instante antes talvez eu ainda tivesse podido não ter visto na cara da barata o seu rosto. Mas eis que por um átimo de segundo ficara tarde demais: eu via. Minha mão, que se abaixara ao desistir do golpe, foi aos poucos subindo de novo lentamente até o estômago." (LISPECTOR, 2009, p. 54)
} 
incorpora a perspectiva de Ana que, por sua vez, incorpora a perspectiva do cego. ${ }^{5}$ Como veremos adiante, o encontro com o cego vai marcar o escurecimento do mundo.

\begin{abstract}
E quem a visse teria a impressão de uma mulher com ódio. Mas continuava a olhá-lo, cada vez mais inclinada - o bonde deu uma arrancada súbita jogando a desprevenida para trás, o pesado saco de tricô despencou-se do colo, ruiu no chão - Ana deu um grito, o condutor deu ordem de parada antes de saber do que se tratava - o bonde estacou, os passageiros olharam assustados. Incapaz de se mover para apanhar suas compras, Ana se aprumava pálida. Uma expressão de rosto, há muito não usada, ressurgira-lhe com dificuldade, ainda incerta, incompreensível. O moleque dos jornais ria entregando-lhe o volume. Mas os ovos se haviam quebrado no embrulho de jornal. Gemas amarelas e viscosas pingavam entre os fios da rede. O cego interrompera a mastigação e avançava as mãos inseguras, tentando inutilmente pegar o que acontecia. $\mathrm{O}$ embrulho dos ovos foi jogado fora da rede e, entre os sorrisos dos passageiros e o sinal do condutor, o bonde deu a nova arrancada de partida. Poucos instantes depois já não a olhavam mais. $\mathrm{O}$ bonde se sacudia nos trilhos e o cego mascando goma ficara atrás para sempre. Mas o mal estava feito. A rede de tricô era áspera entre os dedos, não íntima como quando a tricotara. A rede perdera o sentido e estar num bonde era um fio partido; não sabia o que fazer com as compras no colo. E como uma estranha música, o mundo recomeçava ao redor (LISPECTOR, 2016, p. 147-148).
\end{abstract}

A instabilidade produzida pela visão do cego se manifesta em seu corpo: Ana se inclina na direção do cego, ficando numa posição pouco segura no assento, de que modo que, desprevenida, uma arrancada a joga para trás e faz ruir o saco de tricô. O que vai deixá-la em estado de choque: a visão do cego, antes o único homem parado entre os moventes, paralisa Ana, que fica imóvel e sem reação, como se o imitasse. Num outro plano ainda, o próprio evento é já uma interrupção, um rompimento radical na experiência de Ana. O que se rompe aqui são os laços de família, metaforizados no saco de tricô, que perde sua familiaridade, fica áspero entre os dedos. A rede que garantia sua segurança e estabilidade se desfaz. E é como se a protagonista perdesse seu invólucro protetor e se tornasse radicalmente porosa às coisas, numa experiência viva, de intensa exposição ao mundo. O saco de compras cai e partem-se os ovos. O ovo é símbolo da forma bem-acabada, a organização perfeita, no entanto frágil e de delicado equilíbrio, e que traz dentro de si o vivo. Os ovos se quebram e o que escapa pelo saco de tricô é a gema pegajosa, novamente uma imagem da viscosidade, da matéria anterior à forma.

E o impacto do evento desorganizante, como diz o narrador no final do trecho, é que o próprio mundo recomeçará. Como argumentou Nodari sobre o conto, as repercussões da crise não estão circunscritas a um impacto na realidade interna da personagem, elas são "verdadeiros abalos sísmicos, ontológicos, não redutíveis a um evento interior” (NODARI, 2022, s/p).

\footnotetext{
${ }^{5}$ A "obliquação", conceito criado por Nodari, seria "um movimento complexo de desdobramento subjetivo e das posições enunciativas, cuja face mais visível se apresenta quando o sujeito, sem deixar completamente de sê-lo, ocupa também a posição de objeto" (NODARI, 2019, p. 2)
} 
O mal estava feito. Por quê? teria esquecido de que havia cegos? A piedade a sufocava, Ana respirava pesadamente. Mesmo as coisas que existiam antes do acontecimento estavam agora de sobreaviso, tinham um ar mais hostil, perecível... O mundo se tornara de novo um mal-estar. Vários anos ruíam, as gemas amarelas escorriam. Expulsa de seus próprios dias, parecia-lhe que as pessoas na rua eram periclitantes, que se mantinham por um mínimo equilíbrio à tona da escuridão - e por um momento a falta de sentido deixava-as tão livres que elas não sabiam para onde ir. (...) O que chamava de crise viera afinal. E sua marca era o prazer intenso com que olhava agora as coisas, sofrendo espantada. O calor se tornara mais abafado, tudo tinha ganho uma força e vozes mais altas. Na Rua Voluntários da Pátria parecia prestes a rebentar uma revolução, as grades dos esgotos estavam secas, o ar empoeirado. Um cego mascando chicles mergulhara o mundo em escura sofreguidão. (LISPECTOR, 2016, p. 148-149)

Começa aqui o escurecimento do conto: as pessoas que estão "à tona da escuridão", o cego que "mergulhara o mundo em escura sofreguidão" ou, mais adiante, a protagonista que "parecia ter saltado no meio da noite" e toda imagética soturna de sombras e penumbras do Jardim Botânico, como que indiciam um vínculo com o cego. O mundo que recomeça após a visão desorganizadora estará imantado pela figura do homem cego.

Nesse mundo metamorfoseado, as coisas se tornam "hostis", "de sobreaviso", como se estivessem preparadas para um bote. Inicia-se aqui a progressiva "pessoalização" das coisas, que já estava de certa forma antecipada, vale notar, na imagem macabra das árvores rindo da protagonista, então uma metáfora, mas que agora se literaliza na cena do Jardim Botânico. Esse mundo transformado tem como sua marca à contundência, vinculada a intensificação da experiência da personagem: "tudo tinha ganho uma força e vozes mais altas."

Essa pessoalização do mundo será acompanhada, na personagem, por uma erupção de piedade, que explodirá com violência. É como se a ruína dos laços familiares significasse a liberação de uma piedade da protagonista que estava antes contida, limitada ao espaço da casa. E esse mundo pelo qual Ana terá piedade é povoado por coisas estranhas, que lhe impõem resistência; o mundo se torna áspero, como a rede de tricô que deixa de ser "íntima" (LISPECTOR, 2016, p. 148). Ao perder o seu invólucro protetor, avultam-se os poderes das coisas sobre ela. A incrível e dolorosa intensidade do Jardim Botânico deriva do fato de que lá tudo tem o poder de afetá-la:

\footnotetext{
Andando um pouco mais ao longo de uma sebe, atravessou os portões do Jardim Botânico. Andava pesadamente pela alameda central, entre os coqueiros. Não havia ninguém no Jardim. (...) Tudo era estranho, suave demais, grande demais. Um movimento leve e íntimo a sobressaltou — voltou-se rápida. Nada parecia se ter movido. Mas na aleia central estava imóvel um poderoso gato. Seus pelos eram macios. Em novo andar silencioso, desapareceu. Inquieta, olhou em torno. Os ramos se balançavam, as sombras vacilavam no chão. Um pardal ciscava na terra. (LISPECTOR, 2016, p. 150)
} 
Ana vive no Jardim Botânico uma experiência de proximidade radical com o mundo. Como tudo diz respeito a ela, como tudo tem a capacidade de a colocar em questão, o estado em que ela é jogada é de uma atenção ampliada. "Um movimento leve e íntimo" é capaz de a sobressaltar, tudo se torna "grande demais". Um gato, seus pelos, os ramos, suas sombras, um pardal ciscando na terra: nesse "momento de graça" há um elã que faz com que Ana se volte igualmente para cada movimento, ser, objeto ou intensidade particular. Como diz Hélène Cixous, em um comentário tocante sobre a obra de Clarice, mas que parece particularmente agudo para explicar esses "momentos de revelação":

[Para Clarice] tudo o que existe precisa ser salvo, precisa sair do esquecimento que se faz passar por nossa existência cotidiana. E eis que por intermédio dessa obra tudo retorna, tudo nos é devolvido, igualmente, do mais esplêndido ao mais banal, tudo igualmente: tudo aquilo que tem o direito de ser nomeado, posto que é. Cadeira, estrela, rosa, tartaruga, ovo, menino..., maternalmente ela se preocupa com todos os tipos de "filhos". (CIXOUS, 1999, p. 117)

\section{III}

Uma outra maneira de dizer que o mundo se "pessoaliza" no Jardim Botânico é falar que lá todas as coisas podem ter rosto. Isto é, a partilha que há na filosofia de Levinas entre o que é meramente um objeto e o outro, o que detém um rosto, se desestabiliza na literatura de Clarice. O "mundo que recomeça" após a visão do cego mascando chicletes é precisamente isso, um mundo em que todas as coisas têm a capacidade de nos colocar em questão e nos confrontar, em que tudo ao mesmo tempo nos convida à violência e a proíbe. Esse mundo perigoso não se apresenta a nós como algo que está simplesmente a nossa disposição, como fonte de recursos a serem usados: ele impõe resistência aos nossos desígnios, não pode ser manipulado impunemente.

O abalo de natureza ontológica que ocorre no conto demanda de Ana — demanda de nós? - uma disposição outra em face dos seres e das coisas.

\section{REFERÊNCIAS}

BUTLER, Judith. Precarious Life: The Powers of Mourning and Violence. New York: Verso, 2004. 
CIXOUS, Hélène. A hora de Clarice Lispector. Tradução: Rachel Gutiérrez. Rio de Janeiro: Exodus Editora, 1999.

LEVINAS, Emmanuel. Entre nós: Ensaios sobre a alteridade. Petrópolis: Vozes, 1997.

LEVINAS, Emmanuel. Ética e Infinito. Tradução: João Gama. Lisboa: Edições 70, 1982.

LEVINAS, Emmanuel. Liberté et Commandement. Revue de Métaphysique et de Morale, Paris, 58e Année, n. 3, p. 264-272, jul. 1953.

LEVINAS, Emmanuel. Totalidade e Infinito. Trad. João Pinto Ribeiro. Lisboa: Edições 70, 1980.

LIMA, Luiz Costa. A mística ao revés de Clarice Lispector. In: Por que literatura.

Petrópolis: Vozes, 1969.

LISPECTOR, Clarice. A paixão segundo G.H. Rio de Janeiro: Rocco, 2009.

LISPECTOR, Clarice Todos os contos. Org. Benjamin Moser. Rio de Janeiro: Rocco, 2016.

NODARI, Alexandre. Alterocupar-se: obliquação e transicionalidade na experiência literária. Estudos de Literatura Brasileira Contemporânea, Brasília, n. 57, p.1-17, 2019.

NODARI, Alexandre.. "O infamiliar animismo de Clarice Lispector" In: ROSENBAUM, Y.; PASSOS, C. (orgs.). Um século de Clarice Lispector. São Paulo: Fósforo, 2022. (No prelo)

NUNES, Benedito. O drama da linguagem: uma leitura de Clarice Lispector. São Paulo: Ática, 1989.

PENNA, João Camillo. Clarice Lispector's Things: The Question of Difference.

Tese de doutorado. Orientação: Philippe Lacoue-Labarthe e Avital Ronell. University of California, Berkeley, 1993 (s/n).

PONTIERI, Regina Lúcia. Clarice Lispector: uma poética do olhar. Cotia: Ateliê Editorial, 2001.

SANT'ANA, Afonso Romano de. Análise Estrutural de Romances Brasileiros. Petrópolis: Vozes, 1973.

SIMMEL, Georg. Soziologie: Untersuchungen über die Formen der Vergesellschaftung. Leipzig: Duncker \& Humblot, 1908. Disponível em:

https://www.ssoar.info/ssoar/handle/document/54620. Acesso em: 25 jul. 2021.

SOUZA, Carlos Mendes de. Clarice Lispector: Figuras da Escrita. Braga: Ed. Universidade do Minho, 2000. 
Artigo submetido em: 05 ago. 2021

Aceito para publicação em: 14 set. 2021

DOI: https://dx.doi.org/10.22456/2238-8915.117443 